\title{
Dietary supplementation habits of young Canadian athletes
}

\author{
Megan Stadnyk, Jill A Parnell \\ From International Society of Sports Nutrition: 8th Annual ISSN Conference and Expo \\ Las Vegas, NV, USA. 24-25 June 2011
}

\section{Background}

High-performance, adult athletes consume dietary supplements to increase energy, maintain health or prevent nutritional deficiencies and improve exercise recovery; however, dietary supplementation patterns of young, Canadian athletes remain undetermined. Purpose: 1) Determine the types and frequency of dietary supplement use in young athletes. 2) Determine preferred means of educational media for this demographic.

\section{Methods}

A content validated, reliability tested questionnaire was developed to assess dietary supplement use, motivation for supplementation, and preferred means of education. 136 male and 247 female athletes (11-25 years) completed the questionnaire on site by recall.

\section{Results}

93\% of athletes report taking some form of dietary supplement with multivitamins, vitamin $C$, calcium, and sport drinks as the most frequent daily occurrences (30.5\%, 29.2\%, 27.6\% and $19.8 \%$ respectively). $18.8 \%$ report ingesting energy drinks within the month. The top three reasons for supplement use include: stay healthy $81.0 \%$, increase energy $56.5 \%$, and enhance immune system $52.6 \%$. Family and friends are the primary source of information; however, their preferred means of education were individual consultation, presentations, and the internet.

\section{Conclusion}

Dietary supplement use is common in young athletes. They would prefer to be educated by professionals in individual consultations and presentations; however, they are relying primarily on friends and families. There

Department of Physical Education and Recreation Studies. Mount Royal University, Calgary, Alberta, Canada, T3E 1W9 is a high use of dietary supplements in this demographic yet they lack reliable information. It is essential to develop nutrition education programs for young athletes and to identify the risks and benefits of supplement use in this population.

Published: 7 November 2011

doi:10.1186/1550-2783-8-S1-P22

Cite this article as: Stadnyk and Parnell: Dietary supplementation habits of young Canadian athletes. Journal of the International Society of Sports Nutrition 2011 8(Suppl 1):P22.
Submit your next manuscript to BioMed Central and take full advantage of:

- Convenient online submission

- Thorough peer review

- No space constraints or color figure charges

- Immediate publication on acceptance

- Inclusion in PubMed, CAS, Scopus and Google Scholar

- Research which is freely available for redistribution
C Biomed Central

\section{Biomed Central}

